University of Nebraska - Lincoln

DigitalCommons@University of Nebraska - Lincoln

USDA National Wildlife Research Center - Staff Publications
U.S. Department of Agriculture: Animal and Plant Health Inspection Service

February 2003

\title{
Characteristics of current and historical kit fox (Vulpes macrotis) dens in the Great Basin Desert
}

Wendy M. Arjo

U.S. Department of Agriculture, Animal and Plant Health Inspection Service. Wildlife Services, National Wildlife Research Center

Tim J. Bennett

USDA-APHIS-Wildlife Services

Adam J. Kozlowski

Utah Division of Wildlife Resources. Northern Region.

Follow this and additional works at: https://digitalcommons.unl.edu/icwdm_usdanwrc

Part of the Environmental Sciences Commons

Arjo, Wendy M.; Bennett, Tim J.; and Kozlowski, Adam J., "Characteristics of current and historical kit fox (Vulpes macrotis) dens in the Great Basin Desert" (2003). USDA National Wildlife Research Center - Staff Publications. 192.

https://digitalcommons.unl.edu/icwdm_usdanwrc/192

This Article is brought to you for free and open access by the U.S. Department of Agriculture: Animal and Plant Health Inspection Service at DigitalCommons@University of Nebraska - Lincoln. It has been accepted for inclusion in USDA National Wildlife Research Center - Staff Publications by an authorized administrator of DigitalCommons@University of Nebraska - Lincoln. 


\title{
Characteristics of current and historical kit fox (Vulpes macrotis) dens in the Great Basin Desert
}

\author{
Wendy M. Arjo, Tim J. Bennett, and Adam J. Kozlowski
}

\begin{abstract}
We examined the ecological and physical characteristics of den sites for 13 adult kit fox (Vulpes macrotis) in western Utah from December 1998 to February 2001. We also compared current and historical den distribution among habitat types. The number of den sites used was not influenced by home-range size $(P=0.11)$ or season $(P=0.40)$, but was influenced by geographical area. Home-range size was smallest $(P=0.007)$ and the number of dens used was greatest $(P=0.009)$ in mountainous areas. Ecological and physical characteristics of single-use dens $(n=30)$ were compared with those of multiple-use $(n=53)$ and natal dens $(n=8)$. Characteristics that differed between den types included number of entrances $(P=0.0001)$, diameter of entrances $(P=0.003)$, and height of vegetation along transects $(P=0.0001)$. Natal den entrance azimuths were weighted towards a northwesterly aspect $(P=0.0022)$; however, single- and multipleuse den exits appeared to be randomly distributed. Historical changes in kit fox den site selection have occurred since 1959 ( $P<0.0001)$. We characterized more dens in invasive grasslands and fewer in greasewood (Sarcobatus vermiculatus) habitats than previously described. The conversion of native habitat to grassland and the increase in coyote population may have altered kit fox distribution to include mountainous areas not previously described.
\end{abstract}

\begin{abstract}
Résumé : Nous avons étudié les caractéristiques écologiques et physiques des sites occupés par les terriers de 13 renards nains (Vulpes macrotis) adultes dans l'ouest de l'Utah, de décembre 1998 à février 2001. Nous avons également comparé la répartition actuelle des terriers en fonction des divers habitats à leur répartition dans le passé. Le nombre de sites occupés par des terriers n'est pas influencé par la taille du domaine vital $(P=0,11)$, ni par la saison $(P=$ 0,40 ), mais plutôt par la région géographique. C'est en zone montagneuse que nous avons trouvé les domaines les plus restreints $(P=0,007)$ et le nombre de terriers occupés le plus grand $(P=0,009)$. Les caractéristiques écologiques et physiques des terriers occupés une seule fois $(n=30)$ ont été comparées à celles des terriers utilisés à plusieurs reprises $(n=53)$ et à celles des terriers natals $(n=8)$. Les sites varient par le nombre $(P=0,0001)$ et le diamètre $(P=$ $0,003)$ des entrées et par la hauteur de la végétation le long de transects $(P=0,0001)$. Les azimuts de l'entrée d'un terrier natal ont tendance à s'orienter vers le nord-ouest $(P=0,0022)$; cependant, les sorties des terriers à utilisation unique ou multiple semblent réparties aléatoirement. Depuis 1959, les renards ont modifié leur choix d'habitat pour établir leur terrier $(P<0,0001)$. Nous avons trouvé plus de nids dans les prairies herbeuses qui envahissent la région et moins dans les zones de sarcobates vermiculés (Sarcobatus vermiculatus) qu'auparavant. Ce sont probablement la conversion de l'habitat indigène en terrain herbeux et l'augmentation de la population de coyotes qui ont étendu la répartition des renards nains jusque dans les montagnes, ce qui n'était pas le cas dans le passé.
\end{abstract}

[Traduit par la Rédaction]

\section{Introduction}

The kit fox (Vulpes macrotis) is the smallest North American canid ranging in size from 1.4 to $3 \mathrm{~kg}$. This desert camivore is often found in association with arid and shrub-steppe habitats and, along with the closely related swift fox ( $V$, velox), has been described as the most fossorial North American canid. Kit fox dig dens, adapt existing burrows from other species (i.e., badgers (Taxidea taxus)), and opportunistically select dens. They are always associated with dens unless they are hunting, which typically occurs during the cooler nocturnal hours. Kit fox are reliant on dens both for moderation of microclimate in the arid regions that they inhabit and for security from preda- tion by larger-bodied carnivores (Egoscue 1962 and 1975; Golightly and Ohmart 1984). Dens are therefore an important habitat requirement for kit foxes and may also be a confining factor for their distribution (Egoscue 1962; Morrell 1972).

Egoscue $(1962,1975)$ conducted the first intensive investigation of kit foxes on U.S. Army Dugway Proving Ground (DPG), Utah, describing the natural history of kit foxes in relation to denning habitat, reproductive status, and distribution. Den entrance characteristics such as number of entrances, diameter of entrance, and orientation are frequently referenced as important selection factors for many fox species. Rodrick and Mathews (1999) documented natal kit fox dens in the northern Chihuahuan Desert with tall den en-

Received 16 July 2002. Accepted 29 November 2002. Published on the NRC Research Press Web site at http://cjz.nrc.ca on 20 February 2003.

W.M. Arjo ${ }^{1}$ and T.J. Bennett. U.S. Department of Agriculture, Animal and Plant Health Inspection Service, Wildlife Services, National Wildlife Research Center, 9730-B Lathrop Industrial Drive, Olympia. WA 98512, U.S.A.

A.J. Kozlowski. Utah Division of Wildlife Resources, Northern Region, 515 East 5300 South, Ogden, UT 84055, U.S.A.

${ }^{1}$ Corresponding author (e-mail: wendy.m.arjo@aphis.usda.gov). 
trances, although the number of entrances did not influence whether the den site was used as a natal den. The "keyhole"shaped entrance was thought to provide kit foxes easier access to the den and discourage other predators such as coyotes. Coyote populations have increased on DPG in the last 40 years, so entrances that preclude the larger-bodied carnivore are likely to be favored by the kit fox. In addition, den entrance orientation provides microclimate advantages for arctic foxes (Alopex lagopus) in the winter (Chesemore 1969; Smits et al. 1988; Prestrud 1992). Harsh desert climates in the Great Basin Desert might influence the selection of kit fox dens with entrances orientated to decrease den temperature, especially in the summer during the pup-rearing season.

Arid-land foxes select den sites in positions that maximize visibility from the den (Egoscue 1956, 1962; Kilgore 1969; Zoellick et al. 1989; Pruss 1999). Kit fox normally inhabit the flat valley bottoms in xeric areas of the western United States and are negatively associated with surface roughness of an area (Grinnell et al. 1937; Egoscue 1962; Daneke et al. 1984). In addition to terrain, height of vegetation surrounding the dens is also a factor that may play a larger role in den selection during pup-rearing season than at other times. Dens with little vegetation that provide maximum visibility of surroundings and potential predators may be preferred.

On the Naval Petroleum Reserves in California, Koopman et al. (1998) demonstrated that surplus dens were available to the endangered San Joaquin kit fox (Vulpes macrotis mutica), allowing for increased survival. In addition, Reese et al. (1992) and O'Farrell et al. (1987) found more kit fox dens located in grassland habitat in Camp Roberts where disturbance was minimal. Over the last 40 years, the Great Basin Desert has undergone drastic habitat changes as a result of the invasion of cheatgrass (Bromus tectorum). Cheatgrass is a dense, low-growing annual that fills the interstitial space between native shrubs, creating a dense understory of fuels. Fire frequency and intensity have increased on DPG as a result, and large tracts of native Great Basin shrub habitat been converted to monocultural annual grasslands. As habitats have been altered, so too has the availability of small mammal prey species (AGEISS 2001). Changes in DPG habitat and the possible increase in the coyote population may have caused a shift in kit fox denning habitat and a decrease in available den sites. Understanding den characteristics may help to develop effective management and conservation strategies for the kit fox, especially the endangered San Joaquin kit fox. The objectives of this study were to characterize current kit fox dens to document selective factors and availability for the desert carnivore. In addition, we compared historical den site distribution and habitat selection reported by Egoscue from 1952 to 1970 in unpublished field notes with current kit fox den use to determine if habitat changes have affected kit fox den selection.

\section{Study area}

DPG is located $128 \mathrm{~km}$ southwest of Salt Lake City in Tooele County, Utah. The installation covers $3330 \mathrm{~km}^{2}$ of Great Basin Desert habitat. Because of its midlatitude location, this arid region is often characterized as cold desert. Winters are usually cold, and summers are hot and dry, with most precipitation occurring in the spring. Average maximum tempera- tures on DPG range from $3.3^{\circ} \mathrm{C}$ in January to $34.7^{\circ} \mathrm{C}$ in July. Average minimum temperatures can range from $-8.8^{\circ} \mathrm{C}$ in January to $16.3^{\circ} \mathrm{C}$ in July. Mean annual precipitation is $20.07 \mathrm{~cm}$. Most of DPG consists of flat salt playa, remnants from Lake Bonneville, sparsely vegetated with pickleweed (Allenrolfea occidentalis) and the chenopod playa with shadscale (Atriplex confertifolia), gray molly (Kochia americana), and greasewood (Sarcobatus vermiculatus). However, interspersed in the flat terrain are steep mountain ranges that are cooler and receive more precipitation than the surrounding playa flats and are vegetated with sagebrush (Artemesia spp.), horsebrush (Tetradymia glabrata), and rabbitbrush (Chrysothamnus spp.) along the slopes and Utah juniper (Juniper osteosperma) at higher elevations. Vegetative dunes, populated with fourwing saltbush (A. canescens), greasewood, viscid rabbitbrush ( $C$. viscidiflorus), hopsage (Grayia spinosa), dune rabbitbrush ( $C$. nauseosus var. turbinatus), shadscale, and horsebrush, are sparsely distributed along areas of DPG where water retention is great.

Although not historically present as a community type, annual grasslands, mostly exotic annuals, have invaded and dominated large areas of DPG. Over $60 \%$ of the original high desert scrub community described by Vest (1962) as the mixed-brush community and $40 \%$ of the juniper brush community have been lost to exotic weeds. Disturbance from natural and human-caused fires and military maneuvers have allowed for displacement of natural vegetation by exotic annuals such as cheatgrass, tumbling mustard (Sisymbrium altissimum), Russian thistle (Salsola iberica), and peppercress (Lepidium perfoilatum).

Wildlife species are diverse, with the carnivore guild consisting of cougars (Puma concolor), bobcats (Felis rufus), coyotes, kit foxes, and red foxes (Vulpes vulpes). Although pronghorn (Antilocapra americana) and mule deer (Odocoileus hemionus) are present, these are not considered prey items for kit fox. Small mammal species range from blacktailed jackrabbit (Lepus californicus), mountain cottontail (Sylvilagus nuttalli), and Neotoma species to several heteromyid and mice species.

\section{Methods}

\section{Capture, handling, and radiotelemetry}

Kit fox dens were located using radio-tagged kit foxes. Trapping occurred around known kit fox dens and areas suspected of containing kit fox, combined with transect trapping surveys. Kit foxes were captured with double-door box traps $(80 \times 25 \times 25 \mathrm{~cm}$; Tomahawk Live Trap Co., Tomahawk, Wis.) baited with raw chicken or bacon (Covell 1992). Traps were deployed in the evening and checked early each morning to minimize the amount of time that a fox was in the trap. The kit fox was removed from the trap by placing a cotton bag over one end of the trap and coaxing the fox into the bag. Once the animal was in the bag and secured, it could be removed and handled without the use of drugs. Foxes were sexed, weighed, measured, and aged based on tooth wear and body size. Kit foxes were considered juvenile until the breeding season (15 December) following their birth, at which time they were considered adult. Each kit fox weighing over $1 \mathrm{~kg}$ was fitted with a mortality-sensor transmitter weighing $30-50 \mathrm{~g}$ (Holihil, Toronto, Ont., or Advanced Telemetry Systems, Istanti, Minn.). Animals were 
examined for external wounds and parasites, and any lacerations were treated with antiseptic. An area on the neck of the kit fox was shaved and $3 \mathrm{cc}(1 \mathrm{cc}=1 \mathrm{~mL})$ of blood was drawn from the jugular vein for disease analysis. The kit fox was then released from the point of capture.

A portable receiver (Telonics Inc., Mesa, Ariz.) and a handheld three-element Yagi antenna were used to locate animals at least three times a week. In addition, aerial locations were obtained approximately every 3 weeks. Telemetry procedures followed recommendations by White and Garrott (1990). Fox locations were triangulated using the LOCATE software package (Pacer Ltd., Truro, N.S.) with $\geq 2$ bearings taken $\leq 10$ min apart. To minimize triangulation error, bearing angles were maintained between $20^{\circ}$ and $160^{\circ}$ (Gese et al. 1988). Total home ranges for adult kit fox with $\geq 20$ locations were determined using the $95 \%$ adaptive kernel estimator (Worton 1989) with the program CALHOME (Kie et al. 1996). Seasonal home ranges were also calculated for each adult fox. Annual seasons were defined on the basis of behavioral characteristics and changing energetic needs following Schauster et al. (2002): breeding--gestation (15 December - 14 April), puprearing (15 April - 14 August), and dispersal (15 August 14 December) seasons.

\section{Den characterization}

All dens for radio-collared adult foxes were located by radio-tracking animals during the day to their dens. We determined the location of each den using a global positioning system (GPS) to generate a geographic information system (GIS) map layer in ArcView 3.0 (Environmental Systems Research Institute, Inc., Redlands, Calif.). Topographical characteristics such as slope, aspect, and elevation were measured. The physical characteristics of each den and the vegetation cover were described and quantified. Physical characteristics include number of entrances, maximum diameter for each entrance, den entrance azimuths, type of substratum (bare ground, rock, culvert, building, or man-made structure), and maximum height of kick-out mounds. Kit fox are often seen resting on kick-out mounds, and these mounds may provide an elevated area for vigilance. Vegetation height and density were measured at the den and surrounding the den in four cardinal directions (25-m transect). A $1-\mathrm{m}^{2}$ quadrat was used to estimate the percent cover of grasses, shrubs, and bare ground at the center of the den complex and at 5-m increments along each transect. The dominant plant for each sampling unit and the maximum height of the vegetation were also recorded. Visibility from the den was estimated by placing one observer at the den at kit fox level and reading the lowest mark visible on a metre pole located at the end of each transect. Distance to the nearest road and permanent water source was determined using established GIS map layers. Soil classification using the U.S. Geological Survey soil survey GIS map layer and soil descriptions were also examined.

\section{Statistical analysis}

We used a one-way analysis of variance (ANOVA) to test for differences in season and number of dens used by foxes (STATISTIX 7.0, Analytical Software 2000). Three distinct geographical areas (chenopod playa, mountain, and salt playa) were identified as primary kit fox use areas. We used a oneway ANOVA to test for differences between home-range size or den use versus geographic area. Tukey's multiple comparison tests were used to identify differences within significant variables. To determine if there was a relationship between the number of dens used by an individual fox and the size of the home range or number of radio days, we used a regression analysis.

Dens in which foxes were only located once were considered single-use dens. To test for difference between singleuse, multiple-use, and natal dens, we used a one-way ANOVA followed by a Tukey's multiple comparison test. Data were first tested for normality using a Shapiro-Wilks' test. Proportional data, such as vegetation cover measurements, do not usually meet the requirements for normality (Zar 1996); therefore, we used an arcsine transformation to normalize the data. Other data that were not normally distributed were transformed using a $\log$ or square-root transformation. If data could not be normalized, a Mann-Whitney nonparametric test was employed. Raleigh's test for circular uniformity (Zar 1996) was used to determine whether the den exit azimuths were randomly distributed. If the Raleigh's test returned a nonrandom result, the mean azimuth was calculated and a $V$ test was used to determine if the aspect data was in fact clustered around a mean angle (Zar 1996). Type of substrate, habitat type, and soil classification were categorical data; therefore, we applied a $\chi^{2}$ test for heterogeneity for these three characteristics. In addition, we compared historical den habitat with current den habitat using a $\chi^{2}$ test. All test were considered significant at the $P \leq 0.05$ level.

\section{Results}

\section{Capture, handling, and radiotelemetry}

We captured 27 kit fox, 10 females and 17 males, from December 1998 through February 2001. Twenty adults and 7 juveniles were radio-collared and monitored. Two of the juveniles were monitored as adults. Only 13 adults with $\geq 20$ locations and associated with dens were used in the den analyses. The radio days for 13 adults was $507 \pm 217.67$ days (range 100-873) and the number of dens used was $9.69 \pm$ 5.15 . We found no relationship between the number of days radio-collared and the number of dens used by an adult kit fox $\left(R^{2}=0.09, F_{[1,12]}=0, P=0.97\right)$.

Total home-range size and seasonal home ranges were calculated for each adult fox. We found no relationship between home-range size and number of dens used by foxes $\left(R^{2}=0.14, F_{[1.12]}=2.94, P=0.11\right)$ or between number of radio days and home-range size $\left(R^{2}=-0.013, F_{[1,12]}=0.85\right.$, $P=0.38$ ). Home-range size did not differ among seasons $\left(F_{[2,37]}=0.57, P=0.57\right)$ nor did the number of dens used $\left(F_{[2,27]}=0.95, P=0.40\right)$. We found dens to occur in three distinct geographic areas: salt playa, chenopod playa, and mountains. Home-range size for foxes in these three geographical areas varied $\left(F_{[2,12]}=8.57, P=0.007\right)$. Home-range size for mountain kit foxes $(n=6)$ was smaller (1151.1 \pm 285.9 ha) than that for salt playa foxes $(P=0.007)$, which had the largest home range $(n=3,4308.7 \pm 2076.8$ ha). Salt playa foxes also had larger home ranges $(P=0.016)$ than did chenopod playa foxes $(n=4,1328.6 \pm 1130.6$ ha $)$. There 
Table 1. Characteristics measured at single-use, multiple-use, and natal kit fox (Vulpes macrotis) dens on Dugway Proving Ground, Utah.

\begin{tabular}{lcccc}
\hline Den characteristics & $\begin{array}{c}\text { Single-use den } \\
(n=30)\end{array}$ & $\begin{array}{l}\text { Multiple-use den } \\
(n=53)\end{array}$ & $\begin{array}{l}\text { Natal den } \\
(n=8)\end{array}$ \\
\hline Slope $\left(^{\circ}\right)$ & $17.63 \pm 12.71$ & $14.73 \pm 12.19$ & $12.0 \pm 13.54$ & 0.43 \\
Elevation $(m)$ & $1407.7 \pm 82.91$ & $1413.6 \pm 76.51$ & $1388.9 \pm 79.16$ & 0.70 \\
Height of kick-out mound (cm) & $8.0 \pm 10.22$ & $5.7 \pm 14.65$ & $3.77 \pm 8.36$ & 0.33 \\
Number of entrances & $1.32 \pm 0.67$ & $2.45 \pm 1.70$ & $5.5 \pm 2.98$ & $<0.0001$ \\
Diameter of entrance $(\mathrm{cm})$ & $35.16 \pm 23.33$ & $28.77 \pm 16.97$ & $22.36 \pm 6.1$ & 0.003 \\
Distance to water $(\mathrm{km})$ & $3.45 \pm 0.43$ & $3.41 \pm 0.31$ & $3.42 \pm 0.43$ & 0.88 \\
Distance to roads $(\mathrm{m})$ & $474.47 \pm 468.68$ & $364.02 \pm 399.27$ & $393.38 \pm 387.25$ & 0.52 \\
Visibility $(\%)$ & $34.27 \pm 35.05$ & $35.63 \pm 39.28$ & $37.57 \pm 33.56$ & 0.90 \\
Percent cover at den & $27.32 \pm 16.55$ & $23.05 \pm 17.42$ & $17.85 \pm 15.31$ & 0.32 \\
Vegetation height at den $(\mathrm{cm})$ & $26.45 \pm 18.60$ & $20.43 \pm 18.54$ & $28.63 \pm 33.02$ & 0.37 \\
Percent grass & $23.69 \pm 22.51$ & $22.14 \pm 19.41$ & $23.48 \pm 24.35$ & 0.33 \\
Percent bare ground & $56.02 \pm 22.41$ & $58.09 \pm 21.38$ & $56.49 \pm 23.17$ & 0.17 \\
Percent "other" vegetation & $5.20 \pm 13.91$ & $5.20 \pm 13.71$ & $4.69 \pm 13.91$ & 0.90 \\
Percent shrub cover & $8.74 \pm 12.92$ & $7.39 \pm 11.77$ & $9.11 \pm 14.19$ & 0.06 \\
Vegetation height along transects $(\mathrm{cm})$ & $26.83 \pm 19.09$ & $23.25 \pm 17.81$ & $29.13 \pm 26.03$ & $<0.0001$ \\
\hline
\end{tabular}

Note: Values are means \pm standard deviation.

Table 2. Habitat type and denning substrate of 91 kit fox dens on Dugway Proving Ground, Utah.

\begin{tabular}{lccc}
\hline & $\begin{array}{l}\text { Single-use dens } \\
(n=30)\end{array}$ & $\begin{array}{l}\text { Multiple-use dens } \\
(n=53)\end{array}$ & $\begin{array}{l}\text { Natal dens } \\
(n=8)\end{array}$ \\
\hline Denning substrate & & & 1 \\
$\quad$ Rock & 13 & 24 & 6 \\
$\quad$ Hummock-earth & 14 & 28 & 0 \\
$\quad$ Man-made & 3 & 2 & 1 \\
Habitat type & 4 & 5 & 3 \\
$\quad$ Vegetated dune & 12 & 33 & 1 \\
Grassland & 1 & 4 & 2 \\
Pickelweed & 3 & 6 & 1 \\
Chenopod-greasewood & 8 & 4 & 0 \\
$\quad$ Shrub-steppe - mixed brush & 2 & 1 & \\
$\quad$ Urban & & & \\
\hline
\end{tabular}

was no difference in home-range size between mountain and chenopod playa kit fox $(P=0.97)$. The average number of dens used by foxes in these three geographic areas also varied $\left(F_{[2,12]}=15.24, P=0.009\right)$. Mountain kit fox used more dens than did chenopod playa $(P=0.002)$ and salt playa foxes $(P=0.004)$, but there was no difference in den numbers between chenopod playa and salt playa foxes $(P=$ 0.99 ).

\section{Den characterization}

We located and characterized 91 kit fox dens. Multipleuse dens accounted for 53 of these, 30 were single-use dens, and 8 were natal dens. Results suggest that number of entrances, diameter of entrances, and vegetation height surrounding the den exhibit significant variation between the den classes and may be selective factors for kit fox den site selection (Table 1). Single-use dens had the fewest entrances but the largest diameter entrances. Natal dens, however, had the largest number of entrances and the smallest entrance diameters. The number of den entrances at natal dens differed between both single-use $(P=0.0001)$ and multiple-use dens $(P=0.0001)$. Number of den entrances between single-use and multiple-use dens also differed $(P=0.006)$. Differences in diameter of entrances were only observed between singleuse and natal dens $(P=0.002)$. Although natal dens had diameter entrances smaller than those of multiple-use dens, this difference was not significant $(P=0.076)$. Vegetation height along transects at natal dens was the highest and differed from that of multiple-use dens $(P=0.0008)$. Singleuse and multiple-use dens also varied in vegetation height along transects $(P=0.0006)$, with multiple-use dens having the lowest vegetation height.

The type of denning substrate $\left(\chi^{2}=5.72,4 \mathrm{df}, P=0.22\right)$ and the habitat type $\left(\chi^{2}=11.23,10 \mathrm{df}, P=0.34\right)$ were not different between types of dens (Table 2). Five dens were located in or under man-made structures such as culverts or buildings; however, none was used as a natal den. Soils were grouped into two categories based on depth and drainage and were not different between the dens $\left(\chi^{2}=0.87,2 \mathrm{df}, P=\right.$ $0.65)$. The den entrance azimuths of single-use $(P>0.05)$ 
and multiple-use $(P>0.05)$ dens appear to be randomly distributed. However, natal den entrance azimuths $(z=4.239$, $n=44, P=0.014)$ were not randomly distributed but were clustered around a mean azimuth of $344^{\circ}(u=2.825, n=44$, $P=0.0022$ ).

Den site habitat selection was significantly different between historical and current dens $\left(\chi^{2}=99.78,5 \mathrm{df}, P<\right.$ 0.0001 ). The den site habitat types that contributed the most to the total $\chi^{2}$ value were greasewood and grassland, followed by shrub-steppe, chenopod, pickleweed, and stable dune. Egoscue (unpublished data) recorded the habitat type of 55 dens of which $41(74.5 \%)$ were in greasewood and none $(0 \%)$ was in grassland habitats. We recorded the habitat type of 91 dens, three of which were excluded for analysis because they did not meet the assumptions of a $\chi^{2}$ test. Four $(4.5 \%)$ of the 88 remaining dens were in greasewood and 48 $(54.5 \%)$ were in grassland. We also recorded $13(14.8 \%)$ dens in shrub-steppe habitat and six $(6.8 \%)$ in the pickleweed habitat, whereas Egoscue recorded no $(0 \%)$ dens in either of those habitat types.

\section{Discussion}

Den availability is important to the survival of kit fox populations in that dens provide shelter from temperature extremes, moist microclimate, escape from predators, and a place to rear young. Koopman et al. (1998) found that den use varied between seasons for San Joaquin kit fox on the Naval Petroleum Reserve (NPRC) in California, with more dens used during dispersal season. In addition, an increase in den use at Camp Roberts was correlated with an increase in the number of days that an animal was radio-collared (Reese et al. 1992). Average number of dens used throughout the study for adult foxes was similar to den use reported in other studies, although monitoring periods varied (Hall 1983; Reese et al. 1992; Koopman et al. 1998); however, home-range size, number of days radio-collared, and season did not influence kit fox den use on Dugway Proving Ground. Koopman et al. (1998) hypothesized that there is a surplus of dens at NPRC, but it is likely that most of the dens are used over time. We did not see a seasonal change in den use for foxes, which may suggest a limited quantity of suitable dens.

Although no dens were excavated for the purpose of this study, previous research has documented kit fox dens extending from 1.3 to $3.0 \mathrm{~m}$ below the surface (Egoscue 1956; Morrell 1972; O'Neal et al. 1987). Typically a sleeping chamber or enlarged tunnel was found at the deepest part of the den, and a separate chamber or tunnel closer to the surface was used for food storage. Excavated dens were typically found to spiral below ground with multiple intersecting tunnels branching in different directions towards the surface. These findings are supported by surface observations of multiple den entrances with variable aspects on our study area. We did not observe kit fox excavating any new dens during our study; however, they would frequently modify abandoned dens, man-made structures, or rock crevices.

Kit fox on DPG appear to be influenced by number of den entrances and diameter of entrances when selecting multipleuse and natal den sites. Studies of arctic fox dens have routinely discovered multiple entrances at active den sites (Smits et al. 1988; Smits and Slough 1993; Nielsen et al.
1994); however, others have found no difference (Pruss 1999; Rodrick and Mathews 1999). Kit fox on DPG appear to be influenced by the number of available entrances when selecting den sites, especially natal dens. These results are largely explained by behavior; kit fox are fossorial animals, and the longer duration spent at a den site and the more animals associated with a den, the more likely they are to dig new entrances. Kit foxes may also be selecting den sites based on the availability of entrances or the potential for digging more entrances to provide quick access in case of a threat. Rodrick and Mathews (1999) found that natal kit fox dens in the northern Chihuahuan Desert had taller entrances than did nonnatal dens. However, kit fox on our study site appear to select natal and multiple-use den sites with small den entrance diameters. This supports the hypothesis that kit foxes on DPG preferentially select dens with small entrance diameters and avoid those with larger entrances to reduce the potential for predation by larger-bodied carnivores. Coyotes were the main cause of mortality of the DPG kit fox population (AGEISS 2001). Bat-eared fox (Otocyon megalotis) pups in east and southern Africa take refuge in small entrance dens to discourage predation by larger carnivores (J.A.J. Nel, personal communication), which tends to support our findings.

Several studies of arctic fox dens have discovered a significantly larger number of den entrances oriented in a southerly aspect (Chesemore 1969; Smits et al. 1988; Prestrud 1992; Nielsen et al. 1994), which is hypothesized to provide thermal and microclimatic advantages as well as protection from predominant summer winds in the harsh arctic climate. Pruss (1999) and Jackson and Choate (2000) examined swift fox den orientation and found no significant deviation from a random distribution. On DPG we found that single- and multiple-use den entrance azimuths were randomly distributed; however. natal den entrance aspects exhibited a significant northwesterly trend. Neilsen et al. (1994) found that arctic fox dens in the breeding season were constructed to minimize exposure to winds. Winds are predominately from the southeast in the summer on DPG, and orienting natal den entrances in a northwesterly direction may provide additional protection from the desiccating summer wind.

We found differences in vegetation height and shrub cover surrounding dens to be an important variable between the three den classes. Previous investigations of fox den sites have focused heavily on vegetation surrounding dens (Jackson and Choate 2000), and only a small number have quantified vegetation directly on the den site (Chesemore 1969; Uresk and Sharps 1986; Pruss 1999). Multiple-use dens on DPG had the lowest mean vegetation height and shrub cover, followed by single-use dens, whereas natal dens had the highest vegetation and most shrub cover surrounding the den. Zoellick et al. (1989) demonstrated that natal kit fox dens had low surrounding vegetation heights to maximize the probability of detecting approaching predators. Alternatively, it is possible that taller vegetation surrounding natal dens provides concealment from predators and a higher concentration of invertebrate prey items (Pruss 1999) such as grasshoppers (Acrididae), beetles (Coleoptera), and Mormon crickets (Anabrus spp.). Kit foxes on DPG appear to be dependent on periodic localized population explosions of Mormon crickets (AGEISS 2001). Anecdotal observations suggest 
that kit fox inhabiting areas with Mormon cricket infestations will move to dens in areas that are closer to localized swarms. A higher proportion of shrub cover surrounding these dens could provide habitat for Mormon crickets, which would then allow kit fox pups to fulfill a large part of their caloric needs and significantly reduce energy expenditures of adults. Although shrubs have the potential to decrease visibility from the dens, kit fox typically select areas with low vegetation height and $\leq 10 \%$ shrub cover surrounding the den, which could minimize any effects on visibility and the potential to observe approaching hazards.

Although Hall (1983) and Reese et al. (1992) found kit foxes denning on moderate slopes, kit foxes on Dugway were using relatively steeper slopes. Kit foxes inhabiting the mountainous areas had small home ranges, most likely because of food availability (AGEISS 2001) and available dens. Concomitant with an increased use of rugged terrain is the adoption of rock outcrops as denning substrate. We found no significant variation between the proportion of rock dens in each of the three den classes; however, $41 \%$ of the dens were in rock substrate, including one of the eight natal dens. This is considered an uncharacteristic substrate and previously only observed for dispersing juvenile foxes (Hardenbrook 1987; O'Neal et al. 1987). More dens were used in mountainous terrain in our study area, perhaps because of access of established crevices. Kit fox may be selecting rock outcrops for increased security from predation by coyotes or for energy conservation (Hardenbrook 1987). The mountainous area of DPG also contains the highest concentration of coyotes, so an increase in the number of dens used by foxes in the area could be related to the increase in coyote presence. A change in denning substrate was seen even over a shorter period of time; TRIES (1997) documented the majority of dens (70\%) as earthen and only $2 \%$ as rock.

DPG habitat has been drastically altered over the last 40 years from cold chenopod desert and greasewood to a cheatgrass-dominated habitat. Although cheatgrass provides excellent habitat for seasonal Mormon cricket infestations, it is also characterized by reduced small mammal diversity and abundance. Small mammal abundance has decreased in the last 40 years (AGEISS 2001), and kit fox have switched prey species from mainly leporids (Egoscue 1975) to insects and heteromyids (AGEISS 2001). Grassland habitats produced the lowest abundance of small mammal species, which suggests that kit fox are hunting in surrounding habitats such as the shrub-steppe and stable dunes (AGEISS 2001). Egoscue $(1956,1962)$ studied kit fox on DPG from 1952 until 1969 , before the invasion of noxious weeds. The majority $(74.5 \%)$ of the foxes studied denned in greasewood and shadscale habitat. Currently, kit foxes on DPG have the majority of their dens $(54.5 \%)$ located in grassland, although they are also denning in the shrub-steppe (14.8\%) and pickleweed $(6.8 \%)$ habitats. Although our study area and Egoscue's study area differ in size. Egoscue originally surveyed our study area but did not find any evidence of foxes using the mountain areas. We therefore believe that it was appropriate to analyze changes in fox denning habitat since 1959 . Cheatgrass had a small presence on DPG during Egoscue's study, mainly limited to sparse understory growth in the shrubsteppe community of the foothills (Vest 1962), and was not available as a community type for kit fox den site selection.
In addition, the remaining greasewood habitat on DPG supports a dense population of coyotes, which are probably excluding kit foxes. Coyotes were rare to absent during Egoscue's studies. Kit foxes may be lured to the introduced grassland habitat by the low growing appearance of suitable denning habitat, as well as the abundance of available invertebrate prey.

Changes to DPG habitat, and subsequently to the prey base, and an increase in the coyote population have caused a shift in the availability and distribution of kit fox dens. The availability of suitable den sites is considered to be an important factor for the maintenance of viable kit fox populations. Our data suggest that any dens with multiple entrances, small $(<26 \mathrm{~cm})$ entrance diameters, northerly entrance aspects, and low vegetation heights with a minimal shrub component surrounding the dens should be considered potentially important for the maintenance of kit foxes on DPG and be considered in any land management decisions.

\section{Acknowledgements}

We dedicate this paper in memory of $\mathrm{H}$. Egoscue, who passed away shortly after completion of the study. He was instrumental in establishing the bases of kit fox biology and we appreciated the opportunity to work with him and his willingness to share his unpublished kit fox data. We also thank S. Bates and J. Martin of the Directorate of Environmental Programs at Dugway Proving Ground for their logistical and financial support. This research was conducted through AGEISS Environmental, Inc., and S. Walker, J.A.J. $\mathrm{Nel}$, and an anonymous reviewer provided helpful suggestions to the manuscript.

\section{References}

AGEISS Environmental, Inc. 2001. Final report for the carnivore ecology study at Dugway Proving Ground. Final report to the Directorate of Environmental Programs, U.S. Army Dugway Proving Ground, Dugway, Utah.

Chesemore, D.L. 1969. Den ecology of the Arctic fox in Northern Alaska. Can. J. Zool. 47: 121-129.

Covell, D.F. 1992. Ecology of swift fox (Vulpes velox) in southeastern Colorado. M.S. thesis, University of Wisconsin, Madison.

Daneke, D., Sunquist. M., and Berwick, S. 1984. Notes on kit fox biology in Utah. Southwest. Nat. 29: 361-362.

Egoscue, H.J. 1956. Preliminary studies of the kit fox in Utah. J. Mammal. 37: 351-357.

Egoscue, H.J. 1962. Ecology and life history of the kit fox in Tooele County, Utah. Ecology, 43: 481-497.

Egoscue, H.J. 1975. Population dynamics of the kit fox in Western Utah. Bull. South. Calif. Acad. Sci. 74: 122-127.

Gese, E.M., Rongstad, O.J., and Mytton, W.R. 1988. Relationships between coyote group size and diet in southeastern Colorado. J. Wildl. Manag. 52: 647-653.

Golightly, R.T., Jr., and Ohmart, R.D. 1984. Water economy of two desert canids: coyote and kit fox. J. Mammal. 65: 51-58.

Grinnell, J.J., Dixon, J., and Linsdale, J.M. 1937. Fur-bearing mammals of California. Vol. 2. University of California Press, Berkeley.

Hall, F.A., Jr. 1983. Status of the San Joaquin kit fox, Vulpes macrotis mutica, at the Bethany wind turbine generating (WTG) project site, Alameda County, California. The Resources Agency, California Department of Fish and Game Report, Sacramento, Calif. 
Hardenbrook, D.B. 1987. Habitat usage and den sites of kit foxes in west-central Nevada. M.S. thesis, Humboldt State University, Arcata, Calif.

Jackson, V.L., and Choate, J.R. 2000. Dens and den sites of the swift fox (Vulpes velox). Southw. Nat. 45: 212-220.

Kie, J.G., Baldwin, J.A., and Evans, C.J. 1996. CALHOME: a program for estimating animal home ranges. Wildl. Soc. Bull. 24: $342-344$.

Kilgore, D.L., Jr. 1969. An ecological study of the swift fox (Vulpes velox) in the Oklahoma Panhandle. Am. Mid. Nat. 81: 512-534.

Koopman, M.E.. Scrinvner, J.H., and Kato, T.T. 1998. Patterns of den use by San Joaquin kit fox. J. Wildl. Manag. 62: 373-379.

Morrell, S.H. 1972. Life history of the San Joaquin kit fox. Calif. Fish Game, 58: 162-174.

Nielsen, S.M., Pedersen, V., and Klitgaard, B.B. 1994. Arctic fox (Alopex lagopus) dens in the Disko Bay Area, West Greenland. Arctic, 47: 327-333.

O'Farrell, T.P., Berry, W.H., and Warrick, G.D. 1987. Distribution and status of the endangered San Joaquin kit fox, Vulpes macrotis mutica, on Fort Hunter Liggett and Camp Roberts, California. U.S. Department of Energy Tropical Report, EG\&G/EM Santa Barbara Operations Report No. EGG 10282-2194.

O'Neal, G.T., Flinders, J.T., and Clary, W.P. 1987. Behavioral ecology of the Nevada kit fox (Vulpes macrotis nevadensis) on a managed desert rangeland. In Current mammalogy. Edited by H.H. Genoways. Plenum Press, New York. pp. 443-481.

Prestrud, P. 1992. Physical characteristics of Arctic fox (Alopex lagopus) dens in Svalbard. Arctic, 45: 154-158.

Pruss, S.D. 1999. Selection of natal dens by swift fox (Vulpes velox) on the Canadian prairies. Can. J. Zool, 77: 646-652.

Reese, E.A., Standley, W.G., and Berry, W.H. 1992. Habitat, soils, and den use of San Joaquin kit fox (Vulpes velox macrotis) at Camp Roberts Army National Guard Training site, California. Report to the U.S. Department of the Army and Air Force National Guard Bureau, EG\&G Energy Measurements, Goleta, Calif.
Rodrick, P.J., and Mathews. N.E. 1999. Characteristics of natal and non-natal kit fox dens in the northern Chihuahuan Desert. Great Basin Nat. 59: 253-258.

Schauster, E.R., Gese, E.M., and Kitchen, A.M. 2002. Population ecology of swift fox (Vulpes velox) in southeastern Colorado. Can. J. Zool. 80: 307-319.

Smits, C.M.M., Smith, C.A.S., and Slough, B.G. 1988. Physical characteristics of Arctic foxes (Alopex lagopus) dens in Northern Yukon Territory, Canada. Arctic, 41: 12-16.

Smits, C.M.M., and Slough, B.G. 1993. Abundance and summer occupancy of Arctic fox (Alopex lagopus) and red fox (Vulpes vulpes) dens in the Northern Yukon Territory, 1984-1990. Can. Field-Nat. 107: 13-18.

TRIES (Texas Research Institute for Environmental Studies). 1997. Canid community ecology and response to Army National Guard training at U.S. Army Dugway Proving Ground, Dugway, Utah. Final report to the Directorate of Environmental Programs at U.S. Army Dugway Proving Ground, Dugway, Utah.

Uresk, D.W., and Sharps, J.C. 1986. Denning habitat and diet of the swift fox in western South Dakota. Great Basin Nat. 46: 249-253.

Vest, D.E. 1962. The plant communities and associated fauna of Dugway Valley in Western Utah. PhD. dissertation, University of Utah, Salt Lake City, Utah.

White, G.C., and Garrott, R.A. 1990. Analysis of radio-tracking data. Academic Press, Inc., New York.

Worton, B.J. 1989. Kernal methods for estimating the utilization distribution in home-range studies. Ecology, 70: 164-168.

Zar, J.H. 1996. Biostatistical analysis. 3rd ed. Prentice Hall Inc., Englewood Cliffs, N.J.

Zoellick, B.W., Smith, N.S., and Henry, R.S. 1989. Habitat use and movements of desert kit foxes in western Arizona. J. Wildl. Manag. 53: 955-961. 